\title{
Current State of Japanese language Education in Serbia and Proposal FOR FUTURE SOLUTIONS
}

\author{
Divna TRIČKOVIĆ \\ Faculty of Philology University of Belgrade, Serbia \\ divna.trickovic@gmail.com
}

\begin{abstract}
The purpose of this paper is to address the state of the education system in Serbia in relation to Japanese language studies, with a particular focus on primary and secondary educational institutions. To start off, I will introduce the institutions where the Japanese language is being taught in Serbia, before turning my attention to the teaching programs (i.e. course guidelines as an accredited national guideline). Following that, I will present our Japanese language textbook writing projects. Finally, I will shed light on the problems we have faced and propose a number of potential solutions.
\end{abstract}

Keywords: national course guidelines; Japanese language textbooks; Serbian students; speaking fluency; contrastive analysis

\section{Povzetek}

Glavni namen tega članka je obravnavati srbski izobraževalni sistem in znotraj tega poučevanje japonskega jezika, s poudarkom na osnovnošolskem in srednješolskem izobraževanju. Najprej bom predstavila ustanove, $v$ katerih poteka poučevanje japonskega jezika, nato se bom posvetila njihovim programom (tj. smernicam programov znotraj splošnih nacionalnih smernic). Nadalje bom predstavila projekte, ki se posvečajo pisanju učbenikov japonskega jezika. Pri pisanju učbenikov smo naleteli na več problemov, ki jih bom predstavila in ponudila rešitve zanje.

Ključne besede: smernice nacionalnega programa; učbeniki japonskega jezika; srbski študenti; tekoči govor; primerjalna analiza 


\section{Serbian educational institutions participating in Japanese language studies}

To begin with, I will try and present the educational institutions in Serbia taking part in Japanese language studies, as well as give a brief overview of their history. I will mention all of the institutions, starting at the university level and making my way down to the elementary school level. I have attempted to include every institution I am familiar with that offers certain continuity in respect to Japanese language studies. It is worth noting that, only after my research on this topic had begun, did I become aware these circumstances merit further investigation, especially when it comes to smaller towns. This, however, is a task to be undertaken at another time.

To my knowledge, an organized research into Japanese language studies in Serbia has never been attempted, and I was therefore unable to find any reports on this topic. My endeavour at researching this is, in a way, a pioneering one, and has been made possible by valuable and congenial relations between Japanolgists - members of the Faculty of Philology at the University of Belgrade, as well as thanks to the kindness of Mr. Nenad Bosić, head of the Centre for Foreign Languages at the Kolarac People's University, members of the Association of Japanologists of Serbia, and the Embassy of Japan in the Republic of Serbia.

A crucial institution in regards to Japanese language studies in Serbia is the Section for Japanese Language, Literature and Culture, a part of the Department of Oriental Studies at the Faculty of Philology, University of Belgrade. The Section has been an integral part of the Department for 40 years and has been continuously educating professors of Japanese Studies, who are teaching not only in Serbia, but in a broader region as well. To be precise, it was on 11 November 1976 that Prof. Ljiljana Marković, PhD, held the first Japanese language lecture at the Faculty of Philology in Belgrade, as part of an elective subject. In 1985, the Faculty introduced the 4-year-long educational course for Japanologists, the first of its kind in the entire Balkan region at the time. The course is still available to students. Japanese language studies are now conducted under the module entitled Japanese Language, Literature, and Culture, with most of the lectures being held by employees of the Section for Japanese Language, Literature and Culture, along with a constantly changing number of teaching assistants and PhD students included in the teaching process. The Department currently employs two full professors, one of whom is a native speaker, four associate professors, and three assistant professors. Two foreign lecturers are employed owing to cooperation with the Tokyo University of Foreign Studies and alternate every two to four years. One native speaker employed as a teaching assistant has been aiding the lecturing process since its earliest days. The Faculty of Philology staff, therefore, boasts four native speakers - two of whom are permanent employees, while the remaining two are employed temporarily. The remaining staff are native speakers of Serbian. 
Studies at the Faculty of Philology encompass a broad spectrum of Japanese studies, starting with language and linguistics, and continuing with literature, civilization, culture, history and art history studies. While I will not get into the specifics, it is important to note that Japanese studies, as an elective subject, were removed with the introduction of Japanese studies as a major, but were once again introduced in 2000 (under the name Japanese language as an elective subject, known today as Contemporary Japanese language P1-4), which enabled students from other Departments to study Japanese language. The program of this elective course is in many ways similar to secondary school programs in Serbia.

In 1971 the first Japanese language lessons available to the public were held at the Kolarac People's University. They were definitely the first in Serbia, and quite possibly in a broader region. Those very first lessons were held by the late Prof. Dejan Razić, PhD, founder of the Department of Chinese Language at the Faculty of Philology. Lessons at the Kolarac, as the University is popularly known, were held until 1984. Since 1990, when the program was reinstated, lessons have been held regularly, with a brief pause in 1999, during the period of the NATO bombing of Serbia, most likely due to a drop in the number of course attendees. For some time (the precise period, as of the writing of this paper, the author was unable to determine), the Japanese language course at the Kolarac has been successfully headed by Višnja Janošević, a Japanologist and graduate of the Faculty of Philology. This institution offers different course levels, which are mostly aimed at beginners, with the highest proficiency level being approximately under the A2 level.

For a number of years, a Japanese language course was available at the former Megatrend University (today known as University John Naisbitt), part of the Faculty of Geoeconomics, the only private university in Serbia to offer such a course, to our knowledge. Its primary goals, however, were to familiarize economics students with the sociolinguistic characteristics of the language which might be required for other endeavours, as well as to teach them basic-level conversation skills.

At the state University of Novi Sad, elective Japanese language courses are on offer to the public, regardless of studies. The course was introduced at the Faculty of Philosophy at the University of Novi Sad in 2015, with a similar course being offered at the University's Faculty of Technical Science a short time before that. Course proficiency levels largely remain under the $A 2$ level.

In 1992, a Japanese language student group was introduced at the Philological Gymnasium (Second Belgrade Gymnasium) in Belgrade. A class at the Philological Gymnasium consist of 24 students, which are then divided into two groups of 12, based on their primary language subjects. Initially, only half of the 24 students in the class were taught Japanese, with the other 12 students being taught Spanish. Soon, however, entire groups of 24 students were enrolling as primary Japanese language students. This method of enrollment lasted for a number of years, before the previous 
system was reinstated in the second half of the 90's. Today, half of the students in the group study Japanese, while the other half studies Chinese.

At the Philological Gymnasium, five 45-minute lessons a week are dedicated to studying the student's primary language. Three lessons per week are devoted to the secondary language (English). These lessons are attended in groups of 12 students. Two lessons a week are reserved for the student's native language, while three lessons a week are dedicated to literature - students attend these lessons in full, 24-member groups. Additional, specific subjects also exist, such as general or computer linguistics, whose goal is providing a more in-depth study of language.

The late Snežana Đokanović was the first lecturer of Japanese language at the Philological Gymnasium. During this challenging time, she not only managed to procure donations of books and other study materials sorely needed by the school, but also organize a student trip to Japan in 1996, when leaving the country was difficult and the monetary situation was dire, as the country was under heavy economic sanctions. It is to her that many students, including the author of these lines, owe their love of Japanese language and culture. Alongside her professor, Prof. Ljiljana Marković, PhD, she authored the first Japanese language secondary school teaching program in Serbia. Today, Japanese language studies have a firm foothold at the Gymnasium, with the competition during the enrollment process being as tough as in the very beginning. Lecturers Ivona Vasić and Margareta Samoran are exceptional teachers, who nurture in their students the love of Japanese culture, and familiarize them with the legacy of Japan's civilization, something that the teaching program specifies.

Since 2013, the Eighth Belgrade High School (Gymnasium) has been offering Japanese language as an elective subject. The first lecturer was Marko Božović, followed by Mina Marković, who, in turn, was followed by Mina Svirčev and so forth all of them exceptional graduates of Belgrade's Faculty of Philology, who used this valuable experience as a means to further build their careers. The High School has expressed wishes to increase the duration of the course to four years, from the current two, but has yet to implement these changes. The writing of the new program guidelines is currently underway.

In 2014, the Embassy of Japan in the Republic of Serbia, along with the Belgrade branch of the Mitsubishi Corporation, the Association of Japanologists of Serbia and the Faculty of Philology started the Project for Japanese language advancement in primary and secondary schools. The project employs young graduates, many of whom have returned from their studies abroad in Japan, and whose careers can greatly benefit from this kind of experience.

The following tables illustrate the number of primary and secondary schools which included Japanese language courses in recent years. 
Table 1: Project for Japanese language advancement in primary schools 2014-2017

\begin{tabular}{|c|c|c|}
\hline School year & Primary schools & No. of students \\
\hline \multirow[t]{4}{*}{ 2014/2015 } & Primary school Filip Kljajić Fića (Belgrade) & $<200$ \\
\hline & Grades V-VIII & \\
\hline & Primary school Vuk Karadžić (Belgrade) & 23 \\
\hline & Total: 2 & $<223$ \\
\hline \multirow[t]{4}{*}{ 2015/2016 } & Primary school Filip Kljajić Fića (Belgrade) & 10 \\
\hline & Primary school Vuk Karadžić (Belgrade) & $\begin{array}{l}58,48 \text { (I grade- } \\
38, \text { II grade-10) }\end{array}$ \\
\hline & Primary school Kralj Petar Prvi (Belgrade) & $40-50$ \\
\hline & Total: 3 & $98+\alpha$ \\
\hline \multirow[t]{4}{*}{ 2016/2017 } & Primary school Filip Kljajić Fića (Belgrade) & 15 \\
\hline & Primary school Vuk Karadžić (Belgrade) & Unavailable \\
\hline & Primary school Kralj Petar Prvi (Belgrade) & 13 \\
\hline & Total: 3 & $28+\alpha$ \\
\hline \multirow[t]{10}{*}{$2017 / 2018$} & Primary school Filip Kljajić Fića (Belgrade) & Unavailable \\
\hline & Primary school Vuk Karadžić (Belgrade) & Unavailable \\
\hline & Primary school Kralj Petar Prvi (Belgrade) & Unavailable \\
\hline & Primary school Ujedinjene nacije (Belgrade) & Unavailable \\
\hline & Primary school Danilo Kiš (Belgrade) & Unavailable \\
\hline & Primary school Ratko Mitrović (Belgrade) & Unavailable \\
\hline & Primary school Dušan Jerković (Ruma) & Unavailable \\
\hline & First Primary School in Obrenovac (Obrenovac) & Unavailable \\
\hline & Primary school Sestre Ilić (Valjevo) & Unavailable \\
\hline & Total: 9 ( 3 outside of Belgrade) & Unavailable \\
\hline
\end{tabular}

Table 2: Project for Japanese language advancement in secondary schools 2014-2017

\begin{tabular}{rlr}
\hline School year & High schools (Gymnasium) & No. of students \\
\hline $2014 / 2015$ & Zemun Gymnasium (Belgrade) & 112 (60-80) \\
& 4 student groups (one group per grade) & \\
& Gymnasium Jovan Jovanović Zmaj (Novi Sad) & 152 \\
\cline { 2 - 2 } & Total: 2 (1 outside of Belgrade) & 20 \\
\hline $2015 / 2016$ & Zemun Gymnasium (Belgrade) & I grade: 38 \\
& Eighth Belgrade High School (Belgrade) & II grade: 6 \\
& & 11 \\
& Third Belgrade High School (Belgrade) \\
Gymnasium Jovan Jovanović Zmaj (Novi Sad) & 70 \\
Šabac Gymnasium (Šabac) & 80 \\
Čačak High School (Čačak) & 100
\end{tabular}




\begin{tabular}{|c|c|c|}
\hline \multirow[t]{4}{*}{ School year } & High schools (Gymnasium) & No. of students \\
\hline & Gymnasium of Užice (Užice) & 60 \\
\hline & First Niš High School Stevan Sremac (Niš) & 12 \\
\hline & Total: 8 ( 5 outside of Belgrade) & 397 \\
\hline \multirow[t]{9}{*}{ 2016/2017 } & Zemun Gymnasium (Belgrade) & 30 \\
\hline & Eighth Belgrade High School (Belgrade) & $\begin{array}{l}\text { I grade: } 28, \\
\text { II grade: } 19\end{array}$ \\
\hline & Third Belgrade High School (Belgrade) & Unavailable \\
\hline & Gymnasium Jovan Jovanović Zmaj (Novi Sad) & $\begin{array}{l}\text { I grade: } 20 \\
\text { II grade: } 10\end{array}$ \\
\hline & Šabac Gymnasium (Šabac) & 30 \\
\hline & Čačak High School (Čačak) & Unavailable \\
\hline & Gymnasium of Užice (Užice) & Unavailable \\
\hline & First Niš High School Stevan Sremac (Niš) & Unavailable \\
\hline & Total: 8 ( 5 outside of Belgrade) & $137+\alpha$ \\
\hline \multirow[t]{9}{*}{ 2017/2018 } & Zemun Gymnasium (Belgrade) & Unavailable \\
\hline & Eighth Belgrade High School (Belgrade) & Unavailable \\
\hline & First Niš High School Stevan Sremac (Niš) & Unavailable \\
\hline & Gymnasium Uroš Predić (Pančevo) & Unavailable \\
\hline & Gymnasium Jovan Jovanović Zmaj (Novi Sad) & Unavailable \\
\hline & Čačak High School (Čačak) & Unavailable \\
\hline & Šabac Gymnasium (Šabac) & Unavailable \\
\hline & Gymnasium Borislav Petrov Braca (Vršac) & Unavailable \\
\hline & Total: 8 (6 outside of Belgrade) & Unavailable \\
\hline
\end{tabular}

The tables were based on course reports available at the start of each year, and therefore do not present some information with complete accuracy (for example, the number of course members at the start of a year differed from the number of students who actually completed the course). With that in mind, they still paint a precise enough of a picture of the scope of Japanese language studies in Serbia, both on a primary and secondary level.

As the tables show, while the number of secondary schools who adopt and maintain this teaching program is mostly stable, the number of primary schools that do so, especially outside of Belgrade, is on the rise. One can also note a constant increase in the number of students - despite data being unavailable for the most recent year, we can assume that the number is consistently rising as evident from the growing number of schools that offer courses. Still, the fact remains that the number of interested students is greatest in the first year of studies, after which there is a 
significant decline. These courses cover the basics of literacy and fundamental forms of Japanese language communication.

Apart from the aforementioned educational institutions, private foreign language schools also offer Japanese language lessons. Courses, often brief, are privately organized by certain institutions in Belgrade, but are also available in other cities in Serbia, such as Novi Sad, Kruševac or Niš. Such courses are often beginner-oriented and persist in no small part due to the personal efforts of enthusiastic teachers. I was unable to gather further details on these courses.

\section{Teaching programs for Japanese language lessons in secondary and primary schools}

As far as the teaching program for Japanese language courses is concerned, two official versions are available. The first one was published in The Official Gazette of the Republic of Serbia - Education Gazette (Službeni glasnik Republike Srbije - Prosvetni glasnik), year LXVI, issue 1, 10 January 2017 (Belgrade), with the pages relevant to Japanese language being 108-122.

This program concerns the courses at the Philological Gymnasium. The guideline regarding elective Japanese language courses in other gymnasiums was published in the Official Gazette of the Republic of Serbia - Education Gazette (Službeni glasnik Republike Srbije - Prosvetni glasnik), year LXIV, issue 18, 11 September 2015 (Belgrade). Both teaching programs were made official by the act of publishing.

The teaching program for the Philological Gymnasium covers all four years of secondary education, while the program for other education institutions of this level encompasses only two years. Even though the plan dictates a drastic difference in the number of lectures ( 5 classes per week for the Philological Gymnasium, in contrast to the 2 classes per week for other schools), the difference in subject matter during the first two years is negligible, which can be explained by the difference in the depth of approach to the matter. In both cases, the grammatical and lexical contents of these two course years remain at the A1 level of proficiency.

These programs first and foremost include a general part which is more or less common for all foreign languages offered in Serbia; this general part, as the programs note, concerns Operational tasks at the language skill level. Even though the names of these language skills are somewhat different, they encompass the following (listed according to program chapter names): 1. Speech comprehension (or Listening); 2. Reading comprehension (or Reading); 3. Verbal expression (or Speaking); 4. Interaction; 5. Written expression (or Writing), and 6. Knowledge of language.

The program for general studies in secondary schools also mentions Thematic units, and notes the following: 
"Thematic units are intertwined and are shared throughout all four years of secondary school. Textbook authors and teachers manage them in accordance with student expertise, student interest and current world events".

The program goes on to mention Themes and situations by domain of language use which substantially, if not completely, match those listed in the Common European Framework of References for Languages (CEFR).

The same note as the one on Thematic units is included in the chapter on Communication functions. Communication functions are listed as the following: 1. Introducing oneself and others; 2. Greetings; 3. Identification and naming persons, objects, parts of the body, animals, colors, numbers and so forth (in relation to Themes); 4. Understanding and issuing simple direction and commands; 5 . Asking and answering questions; 6. Requests and expressions of gratitude and so on.

The chapter Program contents (or Grammar content, as the chapter is named in the program for the Philological Gymnasium), reads the following:

"All grammar content is introduced with as few grammar explanations as possible, unless the students insist on an explanation. The knowledge of grammar rules is evaluated and graded based on their use in a specific communication context, without insistence on explicit knowledge of grammar rules".

These instructions clearly indicate a change in the dominant theoretical principle in an attempt to distance language education from the traditional forms of teaching which are almost completely reliant on grammar patterns and thus neglectful of students' communication skills. The chapter Methods of realizing the program specifies how to achieve this and structure a lecture in relation to the subject matter so as to allow for greater student participation in class, as well as stimulate students to set study goals independently.

The chapter Mediation is included in the program for fourth-year students, and encompasses written and spoken translation, as well as retelling and restating a message. Mediation is certainly present in some form in class from the very first lecture, but in the fourth year of studies it becomes unambiguous and included in the program.

Grammatical and lexical content included in the third and fourth year of the Philological Gymnasium, according to the program, enables a student to achieve a level A2 language proficiency.

As far as the primary school program is concerned, work on it is still ongoing, but it would only be natural for it to mirror the secondary school program, with necessary adjustments made to accommodate for younger students. Still, a specific program used by the Project for Japanese language advancement in primary and secondary schools is written mostly by lecturers at the Faculty of Philology and is based on the Marugoto 
and Genki textbooks. The lecturers have demonstrated great care and devotion in this task that they've taken up as volunteer work, and have been working on program quality control, as well. In this respect, Azusa Takami, MA, has proven invaluable in the past. Her responsibilities have been taken over by Miyu Masaki, MA, who generously provided a great deal of information concerning the program for this paper.

\section{Japanese language textbook writing projects}

In 2009, like many of their faculty colleagues before them, Professor Marković and the author embarked jointly on a number of projects with the goal of modernizing language studies, centered around David Little's idea of the autonomous learner (Little, 2007). Extensive teaching experience and the use of contrastive analysis (Tričković, 2010, 2015; Jovanović \& Tričković 2012, 2015) were instrumental to the success of these projects. The initial project included writing papers as a means of motivating students to further explore language and culture (Marković \& Tričković, 2013, 2013a, 2013b, 2014). The second project was the creation of the Japanese script textbook "Kanji" (Marković et al, 2013, 2014; Marković \& Tričković, 2016, 2017a). The third project, realized as the textbook set, entitled "Korak po korak/Step by step" (Marković \& Tričković 2015, 2016, 2017), is the most relevant to this paper.

The aforementioned textbook set "Korak po korak/Step by step" was conceived as a means of covering the basics of Faculty lessons, specifically when it comes to Japanese as an elective subject, and also as a way of fulfilling the need for introducing Japanese language as an elective subject into the secondary education curriculum. The way that the textbooks deal with their subject matter has, therefore, been made appropriate for secondary school students, as well. The authors of the textbooks have received positive feedback from the Philological Gymnasium, as well as Eighth Belgrade High School, while clear data is lacking for other schools. As part of the Project for Japanese language advancement in primary and secondary schools, the Faculty of Philology annually demonstrates and donates these textbook sets to new teachers some of whom embrace them because they feel that presenting the subject matter to students in their native language is beneficial, while others, owing to some nonstandard choices made in the textbooks (such as introducing katakana before hiragana), elect not to use them, or use them only partially. Still, this textbook set is not only the sole textbook set available in Serbian, but is the only set of textbooks accredited as being suitable for use in secondary education, so we believe that its importance in teaching is yet to be recognized. On the other hand, the almost recordbreaking sales numbers speak volume of the market's need for such a textbook. 


\section{Problems and potential solutions}

As far as problems are concerned, I will start with primary schools and move up to higher levels of education, concluding with a suggestion which I believe could benefit others in a broader region.

When it comes to courses organized in primary and secondary schools, with the exception of Eighth Belgrade High School, which introduced the course before the start of the Project for Japanese language advancement in primary and secondary schools, their success is utterly reliant on the backers of this project, which include the Mitsubishi Corporation, the Embassy of Japan in the Republic of Serbia, the Association of Japanologists of Serbia, and the Faculty of Philology. Moreover, should the already humble financial support given to teachers run out, the courses run the risk of being cancelled. The solution to this problem would be a political involvement by the state, which would support the employment of these new teachers. However, judging by the current monetary circumstances in the country, that solution is not likely to come to fruition in any foreseeable future, so all that remains is the hope that the generosity of the sponsors will not reach its limits anytime soon. Furthermore, I have already mentioned that the programs for these courses are currently being written solely by our gracious foreign lecturers; it would be beneficial if, in the future, the burden of this challenging task they have so selflessly undertaken were lessened by the aid of Serbian Japanologists.

As far as the Philological Gymnasium is concerned, a key issue is the fact that its students, should they choose to enroll in the Faculty of Philology, are forced to start their Japanese language education from the ground up, even though Japanese language courses have been part of the Gymnasium for multiple decades, and students are given the chance to prove their knowledge by taking the enrollment test in Japanese. It would prove valuable if, during a future accreditation process, these students would be given a chance to tailor the learning process to their needs, using the already existing system of elective subjects at the Faculty.

Still, the most important and seemingly insurmountable problem of Japanese language students in Serbia on all levels of study, including the highest ones, is that even some of the best students are not capable of active conversation in Japanese, even after graduating from the Faculty. It was this exact problem that motivated the aforementioned projects, as well as the creation of new courses at the Faculty. The textbook authors are of the opinion that the root of this problem is a lack of opportunity to express one's own language needs in Japanese, as the available textbooks and their accompanying programs are often based on the assumption that the Japanese language student will travel to and spend time in Japan, which, as has been concluded based on recent research, simply is not true in the majority of cases (Marković \& Tričković, 2016, 2017, 2017a). 
The number of Japanese language students in Europe, including Serbia, is on the rise (Bučar et al, 2014). And although the current number might be relatively small, their needs should not be overlooked. Our research indicated that a great number of students attend courses primarily due to a personal affinity and love of Japanese culture, whether it be traditional or modern, without a clear intent of travelling to Japan or staying there for an extended period of time (Marković \& Tričković, 2017). If that is the case, chances are they will use Japanese in their own country, within the territory of their native language, rather than in Japan. It is for that reason that we feel it necessary to tailor the learning process to local needs, something that contrastive analysis and the application of its results plays a key role in. This could serve as a foundation of a new methodology which is yet to be built, but one we have already started representing in our new textbooks (Kanji, Step by step). We are also of the opinion that the ability of expressing one's own language needs, which are often motivated by local culture and native language, would boost the motivation for learning a new language which would, in turn, allow at least some courses to surpass the A1 or A2 proficiency levels. These speakers of Japanese language as a foreign language (L2 speakers) would also form a vital link in the economy. Finally, although the languages of the region are different, they can all offer some insight into characteristics of Japanese language which might be imperceptible from the perspective of the Japanese language itself. Thus, by forming a network of good practices, we could help reduce the time needed for reaching fluency in Japanese something the author of this paper believes is the goal of teachers across the globe.

\section{References}

Council of Europe (2001). Common European Framework of Reference for Languages: Learning, teaching, assessment. Cambridge: Cambridge University Press. Retrieved from https://www.coe.int/t/dg4/linguistic/source/framework en.pdf

Jovanović, A., \& Tričković, D. (2012). Contrastive study of metaphor and metonymy driven semantic extensions of the body part word hand "手" in Chinese and Japanese language. Dogu Arastirmalari, A Journal of Oriental Studies. Istanbul: Istanbul University Faculty of Letters, 181-192, Retrieved from http://www.doguedebiyati.com/doguarastirmalari102012-2.pdf

Jovanović, A., \& Tričković, D. (2015). Kontrastivna analiza semantičkih proširenja reči 目 "OKO" i složenica koje ona gradi u kineskom i japanskom jeziku. Komunikacija i kultura online (6). Fokus - forum za interkulturnu komunikaciju, 32-45. Retreived from http://www.komunikacijaikultura.org/KK6.html or http://www.komunikacijaikultura.org/KK6/KK6JovanovicTrickovic.pdf

Little, D. (2007). Language Learners Autonomy: Some Fundamental Considerations Revisited. Innovation in language learning and teaching 1 (1), 14-28.

Marković Lj., \& Tričković, D. (2017a). セルビアにおける漢字学習に関して (About kanji learning in Serbia). Papers Presented at the 29th International Conference on Japanese 
Language Teaching 2016, Vol. 29 日本語教育連絡会議（2016）論文集Vol.29) (Wakai, S., Marković, Lj., \& Tričković, D., Ed.). Filološki fakultet, Kokoro, Andric Istitute, 169-175, Retrieved from http://renrakukaigi.kenkenpa.net/ronbun29.html or http://renrakukaigi.kenkenpa.net/ronbun/2016024.pdf

Marković Lj., Tričković D., Erdeljan M., \& Marić S. (2013). Kanđi. Beograd: Filološki fakultet \& Kokoro.

Marković Lj., Tričković D., Erdeljan M., \& Marić S. (2014). Kanđi (Second edition). Beograd: Filološki fakultet \& Kokoro.

Marković, Lj., \& Tričković, D. (2013a). Japan i ono što ga takvim čini - polazišta, ciljevi i rezultati. Japan i ono što ga takvim čini (pp. 7-12). Beograd: Filološki fakultet Univerziteta u Beogradu.

Marković, Lj., \& Tričković, D. (2013b). Seminarski radovi studenata - metodološki i metodički prilog nastavi stranog jezika i kulture (pp. 169-184). Japan i ono što ga takvim čini. Beograd: Filološki fakultet Univerziteta u Beogradu.

Marković, Lj., \& Tričković, D. (2014a). Collection of student articles as a case-study for the acquisition of discourse: competence and written production in the field of Japanese language and culture. The Proceedings of the 18th Japanese Language Symposium in Europe 28-30 August 2014; Section 10: Japanese Language Education, Subsection of the 14th International Conference of EAJS, Ljubljana, Slovenia. ヨーロッパ日本語教師会 (Association of Japanese Language Teachers in Europe e.V. (AJE)), 201-208.

Marković, Lj., \& Tričković, D. (2015). Korak po korak. Beograd: Filološki fakultet \& Kokoro.

Marković, Lj., \& Tričković, D. (2016). Students for students - The development of a new pedagogy exemplified in kanji ecquisition. 2016 日本語教育シンポジウム（第 20 回 AJE ヨーロッパ日本語教育シンポジゥム; 第 5 回 AIDLG イタリア日本語言語学 • 日本語教育学会）/ Japanese Language Education in Europe 21. The Proceedings of The 20th Japanese Language Symposium in Europe, July 7th-9th, 2016 Ca'Foscari University of Venice (Italy). AJE \& AIDLG, 172-178, Retreived from http://www.eaje.eu/symposium/31 or http://eaje.eu/pdfdownload/pdfdownload.php?index=189-194\&filename=kotomarkovic-trikovic.pdf\&p=venezia

Marković, Lj., \& Tričković, D. (2017). Opening the borders of the Japanese language Discovering and answering the needs of students of Japanese in Serbia. EAJS2017 $15^{\text {th }}$ International Conference of the European Association for Japanese Studies, Lisbon, August 30 -September 2, 2017, 154.

Marković, Lj., \& Tričković, D. (Ed.) (2013). Japan i ono što ga takvim čini. Beograd: Filološki fakultet Univerziteta u Beogradu.

Shigemori Bučar, C. et al. (2014). The CEFR and Teaching Japanese as a Foreign Language. Lingistica, 54, 455-469.

Službeni glasnik Republike Srbije - Prosvetni glasnik, LXIV (18), (11 September 2015)

Službeni glasnik Republike Srbije - Prosvetni glasnik, LXVI (1), (10 January 2017)

Tričković, D. (2010). Kontrastivna proučavanja japanskog i srpskog jezika. In I. Klajn \& P. Piper (Ed.), Kontrastivna proučavanja srpskog jezika: pravci i rezultati (pp. 341-352). Beograd: Srpska akademija nauka i umetnosti, Odeljenje jezika i književnosti. 
Tričković, D. (2015). A view on the verb and the adjective from the Serbian and Japanese language perspective: A contribution to a contrastive analysis of the two languages. In M. Nomachi \& Lj. Popović (Eds.), The Serbian Language as Viewed by the East and the West: Synchrony, Diachrony, and Typology (pp. 173-202). Sapporo: Slavic-Eurasian Research Center Hokkaido University, , Retrieved from http://src-h.slav.hokudai.ac.jp/coe21/publish/no28 ses/index.html or http://src-h.slav.hokudai.ac.jp/coe21/publish/no28 ses/Chapter4 1.pdf 